\title{
Poecilorhynchus perplexus n. g., n. sp. (Trypanorhyncha: \\ Eutetrarhynchidae) from the brownbanded bambooshark, Chiloscyllium punctatum Müller \& Henle, from Australia
}

\section{Bjoern C. Schaeffner • Ian Beveridge}

\author{
B. C. Schaeffner $\bowtie \bullet$ I. Beveridge
}

Department of Veterinary Science, The University of Melbourne, 250 Princes

Highway, Werribee, Victoria 3030, Australia.

e-mail: b.schaeffner@unimelb.edu.au

\begin{abstract}
A new genus of trypanorhynch cestodes is described from the brownbanded bambooshark, Chiloscyllium punctatum Müller \& Henle (Hemiscylliidae) from off Nickol Bay, Western Australia. Poecilorhynchus perplexus n. g., n. sp. is placed in the Eutetrarhynchidae Guiart, 1927 because it is characterised by an elongate, acraspedote scolex with two oval bothria, the absence of bothrial pits, elongate bulbs, the presence of gland-cells within the bulbs and prebulbar organs, retractor muscles inserting at the base of each bulb and an acraspedote strobila. It can be distinguished from all other genera in this family by its possession of a poeciloacanthous typical armature, with a chainette composed of two longitudinal files of uncinate hooks on the external tentacular surface.
\end{abstract}

\section{Introduction}

The Eutetrarhynchidae Guiart, 1927 currently represent one of the most species-rich families of trypanorhynch cestodes. The family was established by Guiart (1927) for trypanorhynchs possessing two bothria, a pars bulbosa not wider than the pars vaginalis, a short strobila and slender tentacles with a basal swelling and tiny, 'curved' hooks of a similar size. Dollfus (1942) provided a more substantial definition for the Eutetrarhynchidae, which included two genera with six different species. He 
(1942) defined the Eutetrarhynchidae as typical heteroacanths ('Hétéracantha typica'), with a heteroacanthous metabasal armature lacking intercalary hook rows. Species of this family were characterised by an acraspedote scolex, two bothria with free posterior margins, absence of bothrial pits ('fossettes sensorielles éversibles' sensu Dollfus, 1942), elongate bulbs and preovarian testes (Dollfus, 1942). Yamaguti (1959) recognised four eutetrarhynchid genera including ten species. Since his account many new taxa were described and Schmidt (1986) already listed six genera with 34 species. In a classification on trypanorhynch cestodes provided by Campbell \& Beveridge (1994), the Eutetrarhynchidae was composed of nine different genera. These authors included additional morphological characters to further define the family, such as the presence of gland-cells within the bulbs and prebulbar organs, and the insertion of the retractor muscle at the base of each bulb. In a monograph on trypanorhynchs, Palm (2004) recognised 13 different genera with 72 species. He suppressed the Tetrarhynchobothriidae Dollfus, 1969 and included the three genera previously placed in this family (i.e. Tetrarhynchobothrium Diesing, 1854; Didymorhynchus Beveridge \& Campbell, 1988; and Zygorhynchus Beveridge \& Campbell, 1988) in the Eutetrarhynchidae, and described eight novel eutetrarhynchid species. More recent studies on this group (Beveridge \& Campbell, 2005; Friggens \& Duszynski, 2005; Campbell \& Beveridge, 2006a,b; 2007; 2009; Beveridge, 2008; Beveridge \& Justine, 2010; Schaeffner \& Beveridge, 2012a,b) have raised the number of taxa to a total of 17 genera with 93 species. Thus to date, the family is not only highly speciose, but is also well defined morphologically. However, the Australian specimens described in the present study represent a new eutetrarhynchid genus, with a unique oncotaxy, which is described below.

\section{Materials and Methods}

A single host individual of the brownbanded bambooshark, Chiloscyllium punctatum (Müller \& Henle) (Orectolobiformes: Hemiscylliidae) was collected from the eastern Indian Ocean off Nickol Bay, Western Australia. Cestodes were fixed in 10\% formalin in situ, later placed in $70 \%$ ethanol and processed as described in Schaeffner et al. (2011) for morphological observation. Serial longitudinal histological sections were prepared for two mature segments, following embedding in paraffin, and staining with haematoxylin and eosin. Line drawings of whole-mounts and 
histological sections were made using an Olympus BH microscope. The terminology of morphological characteristics follows Dollfus (1942) and Campbell \& Beveridge (1994), except that the attachment organs are referred to as bothria following Hyman (1951), Caira et al. (1999) and Jones et al. (2004). The terminology of microthrix shapes follows Chervy (2009). Measurements were made with an ocular micrometer, except for metric data of the oncotaxy. Hook measurements were calculated from SEM micrographs. All measurements are in micrometres, unless otherwise stated, and are given as the range followed by the mean, standard deviation and the number of morphological features measured in parentheses. Circumcortical vitelline follicles are shown on the lateral margins of segments only. Six specimens were used for scanning electron microscopy (SEM) as described in Schaeffner et al. (2011). Micrographs were taken using a Hitachi S-570 scanning electron microscope (Hitachi Ltd.). Typespecimens have been deposited in the South Australian Museum, Adelaide, Australia (SAM); and the United States National Parasite Collection, Beltsville, Maryland, USA (USNPC). The classification of hosts follows Naylor et al. (2012).

\section{Poecilorhynchus n. g.}

\section{Generic diagnosis}

Eutetrarhynchidae Guiart, 1927. Scolex acraspedote, slender, elongate. Scolex peduncle covered with enlarged palmate spinitriches. Bothria two in number, oval. Bothrial pits absent. Pars vaginalis longer than pars bothrialis. Prebulbar organs present. Bulbs elongate, narrow, thick-walled. Retractor muscle originates at base of bulb. Gland-cells present, small, surrounding retractor muscle. Tentacles without basal swelling, with distinctive basal armature. Metabasal armature typical poeciloacanthous; hooks hollow, very small. Hook rows begin on internal surface, terminate on external surface; hook files 1 and 1' not separated. Chainette elements present, with two longitudinal files of uncinate hooks on external surface; slightly spaced from terminal hooks of principle rows. Mature segments acraspedote, elongate. Testes preovarian, in single layer, in two columns. Genital pores marginal, in posterior third of segment. Cirrus-sac oval, thick-walled; cirrus unarmed; internal and external seminal vesicles absent. Ovary bi-lobed in dorso-ventral view, in 
posterior part of segment. Vitelline follicles circumcortical. Uterus simple, tubular, median. Parasitic in bamboo sharks (Hemiscylliidae).

Type- and only species: P. perplexus $\mathrm{n} . \mathrm{sp}$.

Remarks

The new genus belongs within the Eutetrarhynchidae, since it possesses an acraspedote scolex, two bothria lacking bothrial pits, elongate bulbs with gland-cells, presence of prebulbar organs, a retractor muscle inserting at the base of each bulb, and elongate, narrow segments with preovarian testes and an ovary at the posterior extremity. It closely resembles the eutetrarhynchid genera Dollfusiella Campbell \& Beveridge, 1994 and Prochristianella Dollfus, 1946, in its relatively small size, the acraspedote, slender scolex, enlarged microtriches covering the scolex peduncle, slender tentacles with numerous, tiny hooks, and elongate, narrow segments. However, it is readily distinguished from both genera in its unique oncotaxy. Poecilorhynchus perplexus n. g., n. sp. possesses a typical poeciloacanthous tentacular armature with chainette elements. The external surface of the tentacle has two longitudinal files of uncinate hooks separated from each principle row. Not a single species of Dollfusiella, Prochristianella or any other member of the Eutetrarhynchidae shows a similar feature in its oncotaxy. Poecilorhynchus perplexus n. g., n. sp., thus, represents a unique species and the first taxon placed within this family with a typical poeciloacanthous armature.

\section{Poecilorhynchus perplexus n. g., n. sp.}

Type-host: Chiloscyllium punctatum Müller \& Henle (Orectolobiformes: Hemiscylliidae).

Type-locality: Eastern Indian Ocean from Nickol Bay, Western Australia, Australia (2041'S, $\left.116^{\circ} 51^{\prime} \mathrm{E}\right)$.

Site of infection: Spiral intestine.

Type-material: Holotype in SAM (AHC 35632). Paratypes in SAM (AHC 35633-42), and USNPC (106134; for whole-mounts and serial sections). 
Etymology: The generic name alludes to the exceptional tentacular armature of the poeciloacanthous type. The specific name perplexus [Latin for 'confused, intricate or obscure'] indicates the difficulty to describe and illustrate the oncotaxy using conventional methods.

Description (Figs. 1-4)

[Based on 30 whole-mounted specimens, 6 used for SEM, terminal segments from 2 used for longitudinal sections.] Largest mature cestode $5.7 \mathrm{~mm}$ long; total number of segments 9 (7 immature and 2 mature); gravid segments not present; immature specimens 1.2-3.0 (1.5 $\pm 0.4 ; \mathrm{n}=28) \mathrm{mm}$ long. Scolex slender, acraspedote (Figs. 1A,B; 3A), 880-1,190 $(1,025 \pm 57 ; \mathrm{n}=28)$ long; maximum width at level of pars bothrialis, 210-270 (246 $\pm 17 ; \mathrm{n}=14)$ wide; scolex peduncle covered with enlarged, palmate spinitriches (Fig. 3C,D); enlarged spinitriches reach posteriorly almost to posterior end of pars bulbosa (Figs. 1A,B; 3A); pars bothrialis 200-250 $(220 \pm 11$; $\mathrm{n}=$ 28) long. Bothria 2 in number, oval (Figs. 1A; 3B), 200-240 (212 \pm 11 ; $n=13)$ long by $180-205(195 \pm 7 ; n=13)$ wide, with free posterior margins, with or without slight indentation, without thickened rims; proximal bothrial surface covered with smaller, palmate spinitriches (Fig. 3E); bothrial pits absent. Pars vaginalis longer than pars bothrialis, 540-660 (604 $\pm 33 ; \mathrm{n}=28)$ long; tentacle sheaths thin, sinuous (Fig. 1A,B). Pars bulbosa 310-500 (415 $\pm 40 ; n=29)$ long by 175-245 $(202 \pm 16 ; n=29)$ wide; prebulbar organs present (Fig. 1D); bulbs elongate, thick-walled (Fig. 1D), 300-500 (406 $\pm 41 ; \mathrm{n}=56)$ long by 50-70 (62 $\pm 5 ; \mathrm{n}=56)$ wide; bulb width: length ratio 1: 5.0-8.2 (1: $6.6 \pm 0.7 ; \mathrm{n}=56)$; retractor muscle originates at base of bulb (Fig. 1D); gland-cells present, small, surrounding retractor muscle to anterior part of bulb (Fig. 1A,B,D); pars post-bulbosa very short or absent, up to $30(9 \pm 11 ; \mathrm{n}=29)$ long; scolex ratio (pars bothrialis : pars vaginalis : pars bulbosa) 1: 2.2-3.0: 1.3-2.3 (1: 2.7 $\pm 0.2: 1.9 \pm 0.2 ; \mathrm{n}=28)$.

Fully everted tentacles 232-388 (322 $\pm 80 ; n=3)$ long; tentacle diameter 18$20(18 \pm 1 ; \mathrm{n}=10)$ at base, $18-20(19 \pm 1 ; \mathrm{n}=10)$ in metabasal region, $13-18(15 \pm$ $1 ; \mathrm{n}=10$ ) in distal region. Distinctive basal armature present; basal swelling absent; initial rows with uncinate hooks (Fig. 4A-C); uncinate hooks well separated, situated around tentacular base, $4-6(5 \pm 1 ; n=4)$ long, base 3-4 (4 $\pm 1 ; n=4)$ long; bothrial surface with files of three hooks anterior to uncinate basal hooks (Fig. 4A,C); hooks 
on bothrial surface falcate, with broadened base, with blunt tip, of similar size, 6-8 (7 $\pm 1 ; n=7)$ long, base $2-3(3 ; n=3)$ long, representing largest hooks on tentacle.

Metabasal armature typical poeciloacanthous; hooks hollow. Hook files in ascending half spiral rows, begin on internal surface of tentacle, terminate on external surface; hook files 1 and 1' not separated. Proximal metabasal armature: hooks 1(1') flattened, with broadened base, of similar size (Fig. 4D), undergo transition in shape and size towards distal metabasal region (Fig. 2B); initial 4-5 hooks of principle rows with enlarged base, small, with blunt tip, 3-4 (3; $\mathrm{n}=10)$ long, base $1-2(2 ; \mathrm{n}=10)$ long; hooks become larger towards antibothrial and bothrial surfaces, falcate, more erect, with broadened base, without recurved tip; hooks on antibothrial surface falcate, with broadened base, with characteristic sinuous tip (Fig. 4C); hooks on bothrial surface falcate, with broadened base, without recurved or sinuous tip (Fig. 4E, F), 3-4 (3; $n=6)$ long, base $2(n=6)$ long; rows terminate on external surface with two longitudinal files of hooks; hooks of longitudinal files falcate, with broadened base (Fig. 4D), c. $3(n=1)$ long, base c. $1(n=1)$ long; shape of hooks of longitudinal files changes from falcate to uncinate distally.

Mid-metabasal to distal metabasal region: hooks 1(1') falcate, with long base, with blunt tips (Fig. 2B); hooks increase in size towards bothrial and antibothrial surfaces (Fig. 4G), then decrease in size towards longitudinal files on external surface (Fig. 4H,I). Internal surface with falcate hooks, with broadened base, with blunt tips (Fig. 4G); bothrial surface with falcate hooks, with recurved or sinuous tips (Fig. 2B), base not broadened, c. $6(n=2)$ long, base c. $2(n=2)$ long; external surface with falcate hooks, with broadened base, with blunt tips, 3-4 (4; $n=13)$ long, base $2(n=$ 13) long; chainette elements present on external surface (Fig. 2A), composed of two files of hooks, separated from principle rows (Figs. 2A; 4H,I); hooks of chainette elements uncinate, of same size in mid-metabasal armature, 2-3 (2;n=3) long, base $2(\mathrm{n}=3)$ long (Fig. 4H,I), undergo transition in shape and size towards distal metabasal region, larger, rosethorn-shaped (Fig. 2B).

Segments acraspedote; immature segments 20-50 (30 $\pm 10 ; \mathrm{n}=7)$ long by 150-190 (169 $\pm 16 ; n=7)$ wide; mature segments $2,240(n=1)$ long by $240(n=1)$ wide. Genital pores alternate irregularly, in posterior third of segment; pore inconspicuous; cirrus sac ovoid (Fig. 1C,E), $125(\mathrm{n}=1)$ long by $115(\mathrm{n}=1)$ wide; cirrus unarmed; internal and external seminal vesicles absent. Vas deferens obscured by uterus. Testes in single layer, in two columns (Fig. 1C), 90-105 (99 \pm 5 ; $n=15)$ 
long by 60-75 $(69 \pm 4 ; n=15)$ wide, decrease in size towards anterior part of segment; testes 46-49 $(\mathrm{n}=2)$ in number, $41-43(\mathrm{n}=2)$ preporal, 5-6 $(\mathrm{n}=2)$ postporal, exclusively preovarian, absent in region of cirrus sac (Fig. 1C). Vagina c. 5 $(n=1)$ wide, enters genital atrium from posterior aspect (Fig. 1E); vaginal course not observed; seminal receptacle not observed; ovary near posterior extremity of segment (Fig. 1C), tetra-lobed; ovarian lobes $155-160(\mathrm{n}=2)$ long by $40-50(\mathrm{n}=2)$ wide; Mehlis' gland posterior to ovarian lobes (Fig. 1C), c. $70(n=1)$ in diameter; vitelline follicles small, circumcortical, 25-35 (30 $\pm 4 ; \mathrm{n}=20)$ in diameter; uterus median, tubular, simple, extending between rows of testes to anterior extremity of segment; uterine pore not observed.

Remarks

This species shows the typical morphological characters of the Eutetrarhynchidae. However, in possessing two longitudinal files of hooks on the external surface of the metabasal tentacular armature, the oncotaxy is poeciloacanthous. The presence of chainette elements in the metabasal tentacular armature clearly separates the new species from all members within the family.

The tentacles of Poecilorhynchus perplexus n. g., n. sp. are very slender and narrow and the armature is represented by diminutive individual hooks. The largest hooks on the tentacle are less than eight micrometers in length and individual base lengths do not exceed four micrometers. It was not possible to make line drawings of the tentacular armature using conventional morphological methods with a light microscope. Therefore, the description of the oncotaxy is entirely based on SEM micrographs (Fig. 4A-I) and line drawings have been made from micrographs by tracing the hooks (Fig. 2).

\section{Discussion}

The discovery of Poecilorhynchus perplexus, the first eutetrarhynchid taxon with a poeciloacanthous tentacular armature, creates difficulties within the current classifications of trypanorhynchs and further undermines the significance of the tentacular armature as a useful morphological characteristic to classify this group of 
cestodes at higher taxonomic levels. Trypanorhynch taxa have been characterised by a combination of selected morphological features (i.e. two or four bothria, presence or absence of bothrial pits, prebulbar organs and gland-cells) and patterns in their oncotaxy (i.e. homeoacanthous, heteroacanthous or poeciloacanthous armature types) (Campbell \& Beveridge, 1994; Palm, 2004). However, Olson et al. (2010) have demonstrated that many of these characters are homoplasious.

In his monograph on trypanorhynch cestodes Palm (2004) included four families in the superfamily Eutetrarhynchoidea Dollfus, 1969, namely the Rhinoptericolidae Carvajal \& Campbell, 1975, Mixodigmatidae Dailey \& Vogelbein, 1982, Eutetrarhynchidae and Progrillotiidae Palm, 2004, which are characterised by several morphological features, such as prebulbar organs, elongate bulbs and retractor muscles inserting at the base of the bulbs. Moreover, a majority of species possess gland-cells, which are absent only in Shirleyrhynchus aetobatidis (Shipley \& Hornell, 1906) (see Beveridge \& Campbell, 1988), Rhinoptericola megacantha Carvajal \& Campbell, 1975 (see Carvajal \& Campbell, 1975) and Prochristianella jensenae Schaeffner \& Beveridge, 2012 (see Schaeffner \& Beveridge, 2012b). The superfamily combines families with either two (Eutetrarhynchidae and Progrillotiidae) or four bothria (Rhinoptericolidae and Mixodigmatidae) (Palm, 2004). Furthermore, the four families exhibit a combination of different tentacular armature types (i.e. homeoacanthous, heteroacanthous typical/atypical, and poeciloacanthous). Until recently (Campbell \& Beveridge, 1994), the Eutetrarhynchidae represented a welldefined, uniform group of trypanorhynchs. Palm (2004) suppressed the Tetrarhynchobothriidae Dollfus, 1969 and transferred the three genera (Didymorhynchus, Tetrarhynchobothrium and Zygorhynchus) to the Eutetrarhynchidae, based on morphological features, similar life-cycles and results of a cladistic analysis (Palm, 2004). Inadvertently, he combined groups with a homeoacanthous armature (i.e. the former Tetrarhynchobothriidae) with taxa possessing a heteroacanthous typical armature (i.e. the 'typical eutetrarhynchid genera', sensu Palm, 2004). The description of $P$. perplexus adds a third armature type to the Eutetrarhynchidae, furthermore emphasising the significance of prebulbar organs as the most reliable distinguishing morphological feature of this group.

Although a clear definition of a chainette does not exist in the literature (see Schaeffner et al., 2011), we consider the two longitudinal files of hooks in the metabasal armature of $P$. perplexus to be chainette elements, since these hooks differ 
from hooks of the principle rows. This corresponds to the definition of a chainette given by Dollfus (1942), who considered it a longitudinal file of hooks on the external tentacular surface. In Palm's (2004) definition, a chainette consists of one or several longitudinal files, with hooks of a different form and/or size to the ones of the principle and intercalary hook rows. These longitudinal files of hooks are, thereby, either aligned with the principle and/or intercalary hook rows or are not aligned and therefore occurring in multiples.

In recent molecular phylogenetic studies on trypanorhynch cestodes (Palm et al., 2009; Olson et al., 2010) the Eutetrarhynchoidea appeared as a paraphyletic group, in a basal position to representatives of the Tentacularioidea Poche, 1926. Palm et al. (2009) maintained both superfamilies as independent. In contrast, Olson et al. (2010) combined both groups into a single superfamily (the Tentacularioidea), to recognise them as a monophyletic group. The latter authors also erected the suborder Trypanobatoidea, for tentacularioid and eutetrarhynchoid representatives, which formed a separate clade to the remaining trypanorhynch superfamilies (i.e. Gymnorhynchoidea Dollfus, 1935; Lacistorhynchoidea Guiart, 1927 and Otobothrioidea Dollfus, 1942), assigned by them to the suborder Trypanoselachoidea. Both analyses (Palm et al., 2009; Olson et al., 2010) highlighted the subordinate nature of the oncotaxy for the classification of trypanorhynchs at a higher taxonomic level. This not only questions the placement of many taxa in the most recent classifications (Campbell \& Beveridge, 1994; Palm, 2004), but also supports the placement of the new genus with a highly distinct armature type into the family Eutetrarhynchidae.

Acknowledgements The authors are indebted to Bruce Robertson for the collection of material in Western Australia. We are also grateful to Joan Clark (Monash Micro Imaging, Monash University) for taking SEM micrographs. The collecting was funded by the Australian Biological Resources Study, and other aspects by the National Science Foundation (NSF) (PBI award Nos. 0818696 and 0818823 to Janine N. Caira and Kirsten Jensen, respectively). 


\section{References}

Beveridge, I. (2008). Redescriptions of species of Tetrarhynchobothrium Diesing, 1850 and Didymorhynchus Beveridge \& Campbell, 1988 (Cestoda:

Trypanorhyncha), with the description of Zygorhynchus borneensis n. sp. Systematic Parasitology, 69, 75-88.

Beveridge, I., \& Campbell, R. A. (1988). Cetorhinicola n.g., Shirleyrhynchus n.g. and Stragulorhynchus n.g., three new genera of trypanorhynch cestodes from elasmobranchs in Australian waters. Systematic Parasitology, 12, 47-60.

Beveridge, I., \& Campbell, R. A. (2005). Three new genera of trypanorhynch cestodes from Australian elasmobranch fishes. Systematic Parasitology, 60, 211-224.

Caira, J. N., Jensen, K., \& Healy, C. J. (1999). On the phylogenetic relationships among tetraphyllidean, lecanicephalidean and diphyllidean tapeworm genera. Systematic Parasitology, 42, 77-151.

Beveridge, I., \& Justine, J.-L. (2010). Two new species of Prochristianella Dollfus, 1946 (Platyhelminthes, Cestoda) from the blue-spotted stingray, Neotrygon kuhlii (Müller \& Henle, 1841) off New Caledonia. Zoosystema, 32, 643-652. Campbell, R. A., \& Beveridge, I. (1994). Order Trypanorhyncha Diesing, 1863. In: Khalil, L. F., Jones, A. \& Bray, R. A. (Eds.) Keys to the cestode parasites of vertebrates. Commonwealth Agricultural Bureaux International, Wallingford, pp. $51-148$.

Campbell, R. A., \& Beveridge, I. (2006a). Two new species of Pseudochristianella Campbell \& Beveridge, 1990 (Cestoda: Trypanorhyncha) from elasmobranch fishes from the Gulf of California, Mexico. Parasite, 13, 275-281.

Campbell, R. A., \& Beveridge, I. (2006b). Three new genera and seven new species of trypanorhynch cestodes (family Eutetrarhynchidae) from manta rays, Mobula spp. (Mobulidae) from the Gulf of California, Mexico. Folia Parasitologica, 53, 255-275.

Campbell, R. A., \& Beveridge, I. (2007). A new species and new records of Parachristianella Dollfus, 1946 (Cestoda: Trypanorhyncha) from the Gulf of California, Mexico. Comparative Parasitology, 74, 218-228.

Campbell, R. A., \& Beveridge, I. (2009). Oncomegas aetobatidis sp. nov. (Cestoda: Trypanorhyncha), a re-description of $O$. australiensis Toth, Campbell \& 
Schmidt, 1992 and new records of trypanorhynch cestodes from Australian elasmobranch fishes. Transactions of the Royal Society of South Australia, $133,18-29$.

Carvajal, J., \& Campbell, R. A. (1975). Rhinoptericola megacantha gen. et sp. n., representing a new family of trypanorhynch cestodes from the cownose ray, Rhinoptera bonasus (Mitchill, 1815). Journal of Parasitology, 61, 1023-1030.

Chervy, L. (2009). Unified terminology for cestode microtriches: a proposal from the International Workshops on Cestode Systematics in 2002-2008. Folia Parasitologica, 56, 199-230.

Dollfus, R. P. (1942). Études critiques sur les Tétrarhynques du Muséum de Paris. Archives du Muséum National d' Histoire Naturelle, Paris, 19, 1-466.

Friggens, M. M., \& Duszynski, D. W. (2005). Four new cestode species from the spiral intestine of the round stingray, Urobatis halleri, in the northern Gulf of California, Mexico. Comparative Parasitology, 72, 136-149.

Guiart, J. (1927). Classification des tétrarhynques. Association Française pour l'Avancement des Sciences. 50ème session, Lyon, 1926, 397-401.

Hyman, L. H. (1951). The invertebrates: Platyhelminthes and Rhynocoela. The acoelomate Bilateria. Vol. 2. New York: McGraw-Hill, 550 pp.

Jones, M. K., Beveridge, I., Campbell, R. A., \& Palm, H. W. (2004). Terminology of the sucker-like organs of the scolex of trypanorhynch cestodes. Systematic Parasitology, 59, 121-126.

Naylor, G. J. P., Caira, J. N., Jensen, K., Rosana, K. A. M., White, W. T., \& Last, P. R. (2012). A DNA sequence-based approach to the identification of shark and ray species and its implications for global elasmobranch diversity and parasitology. Bulletin of the American Museum of Natural History, 367, 1262.

Olson, P. D., Caira, J. N., Jensen, K., Palm, H. W., Overstreet, R. M., \& Beveridge, I. (2010). Evolution of the trypanorhynch tapeworms: parasite phylogeny supports independent lineages of sharks and rays. International Journal for Parasitology, 40, 223-242.

Palm, H. W. (2004). The Trypanorhyncha Diesing, 1863. PKSPL-IPB Press, Bogor, $710 \mathrm{pp}$.

Palm, H. W., Waeschenbach, A., Olson, P. D., \& Littlewood, D. T. J. (2009). Molecular phylogeny and evolution of the Trypanorhyncha Diesing, 1863 
(Platyhelminthes: Cestoda). Molecular Phylogenetics and Evolution, 52, 351367.

Schaeffner, B. C., Gasser, R. B., \& Beveridge, I. (2011). Ancipirhynchus afossalis n. g., n. sp. (Trypanorhyncha: Otobothriidae), from two species of sharks off Indonesian and Malaysian Borneo. Systematic Parasitology, 80, 1-15.

Schaeffner, B. C., \& Beveridge, I. (2012a). Description of a new trypanorhynch species (Cestoda) from Indonesian Borneo, with the suppression of Oncomegoides and the erection of a new genus Hispidorhynchus. Journal of Parasitology, 98, 408-414.

Schaeffner, B. C., \& Beveridge, I. (2012b). Prochristianella Dollfus, 1946 (Trypanorhyncha: Eutetrarhynchidae) from elasmobranchs off Borneo and Australia, including new records and the description of four new species. Zootaxa, 3505, 1-25.

Schmidt, G. D. (1986). CRC handbook of tapeworm identification. Boca Raton, Florida: CRC Press Inc., 675 pp.

Yamaguti, S. (1959). Systema helminthum. Vol. II. The cestodes of vertebrates. New York: Interscience Publishers Inc., 860 pp.

\section{Captions to Figures}

Fig. 1 Line drawings of Poecilorhynchus perplexus n. g., n. sp. from Chiloscyllium punctatum from Nickol Bay, Western Australia. A, scolex, dorso-ventral view; B, scolex, lateral view; C, mature segment; D, bulb; E, detail of region of cirrus-sac. Abbreviations: c, cirrus; cs, cirrus-sac; ga, genital atrium; t, testis; ut, uterus; va, vagina; vit, vitelline follicle

Fig. 2 Line drawings of the oncotaxy of Poecilorhynchus perplexus n. g., n. sp. from Chiloscyllium punctatum from Nickol Bay, Western Australia. A, schematic representation of the external surface of the mid-metabasal tentacular armature - note space between principle hook rows and two longitudinal files of hooks (chainettes); B, profiles of hooks: 1 , uncinate hook of chainette, mid-metabasal region; 2, uncinate hook of chainette, distal metabasal region; 3, falcate principle hook with enlarged base, internal surface, basal to metabasal region; 4,5 , falcate principle hooks with 
enlarged bases, external surface, metabasal region; 6,7 , hooks $1\left(1^{\prime}\right)$, internal surface, basal region; 8 , hooks $1\left(1^{\prime}\right)$, internal surface, metabasal region; 9 , falcate principle hook with enlarged base and sinuous tip, antibothrial surface, metabasal region; 10, enlarged uncinate hook, most proximal basal region; 11, falcate hook with recurved tip, bothrial surface, basal region; 12, falcate hook with sinuous tip, bothrial surface, basal region

Fig. 3 Scanning electron micrographs of Poecilorhynchus perplexus n. g., n. sp. from Chiloscyllium punctatum from Nickol Bay, Western Australia. A, scolex, lateral view; $\mathrm{B}$, anterior part of scolex; $\mathrm{C}$, enlarged, palmate spinitriches covering scolex peduncle; $\mathrm{D}$, detailed view of palmate spinithrix on scolex peduncle; $\mathrm{E}$, smaller, palmate spinitriches covering proximal bothrial surface

Fig. 4 Scanning electron micrographs of Poecilorhynchus perplexus n. g., n. sp. from Chiloscyllium punctatum from Nickol Bay, Western Australia. A, basal tentacular armature, external surface - note falcate hooks on bothrial surface (arrow); B, basal tentacular armature, antibothrial to external surface - note uncinate hooks at base (arrow); C, basal tentacular armature, internal surface; D, transition from basal to metabasal tentacular armature, external surface; E, transition from basal to metabasal tentacular armature, antibothrial to internal surface - note falcate hooks with sinuous tip on antibothrial surface (arrow); F, transition from basal to metabasal tentacular armature, internal to antibothrial surface; G, metabasal tentacular armature, internal surface; H, metabasal tentacular armature, external surface - note falcate hooks with broadened base of principle hook rows and two longitudinal files of uncinate hooks forming chainette, separated from principle rows; I, detailed view of terminal hooks of principle rows (left) and two longitudinal files of hooks (right) on external surface of metabasal armature - note space between principle hook rows and longitudinal files of hooks 

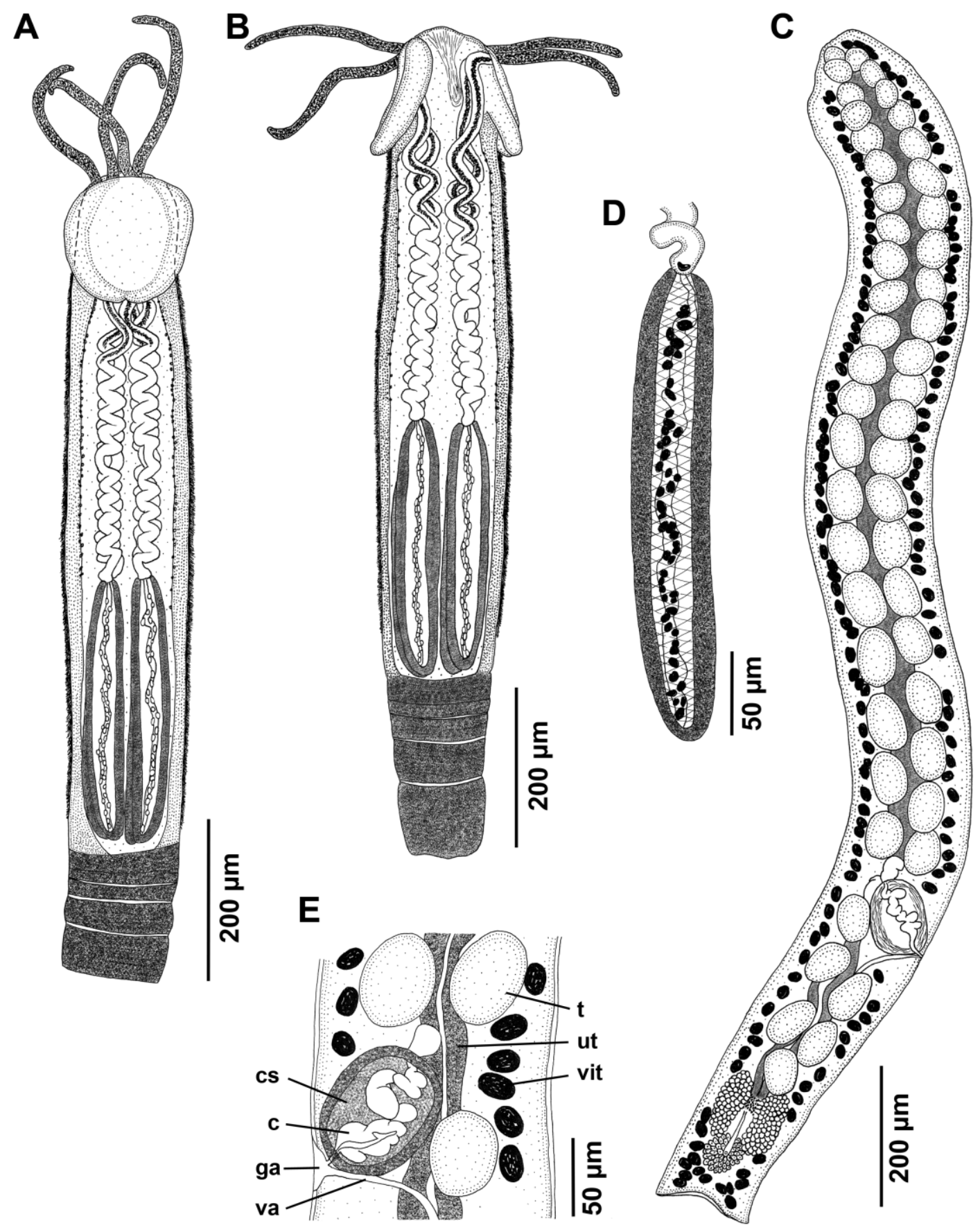

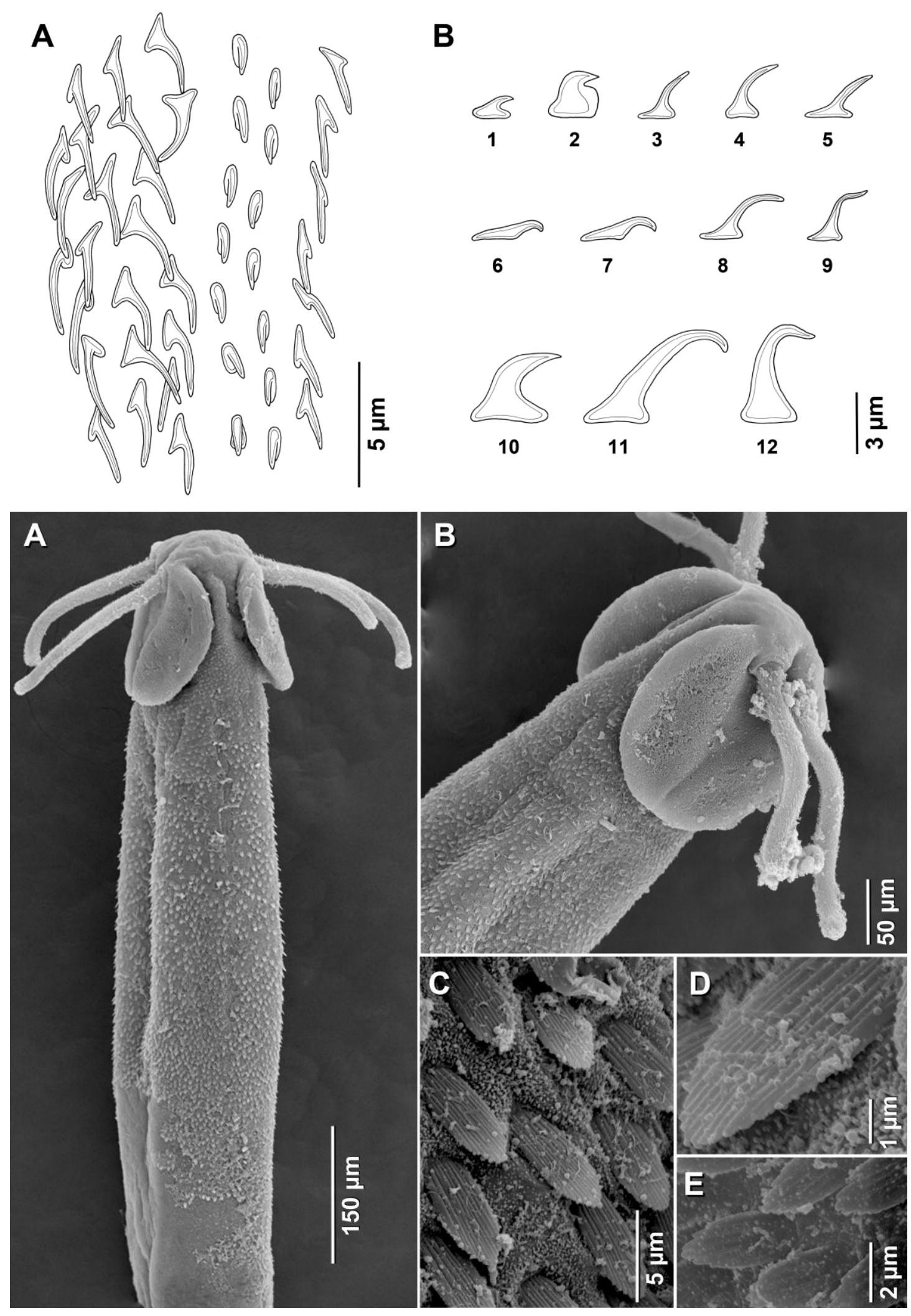


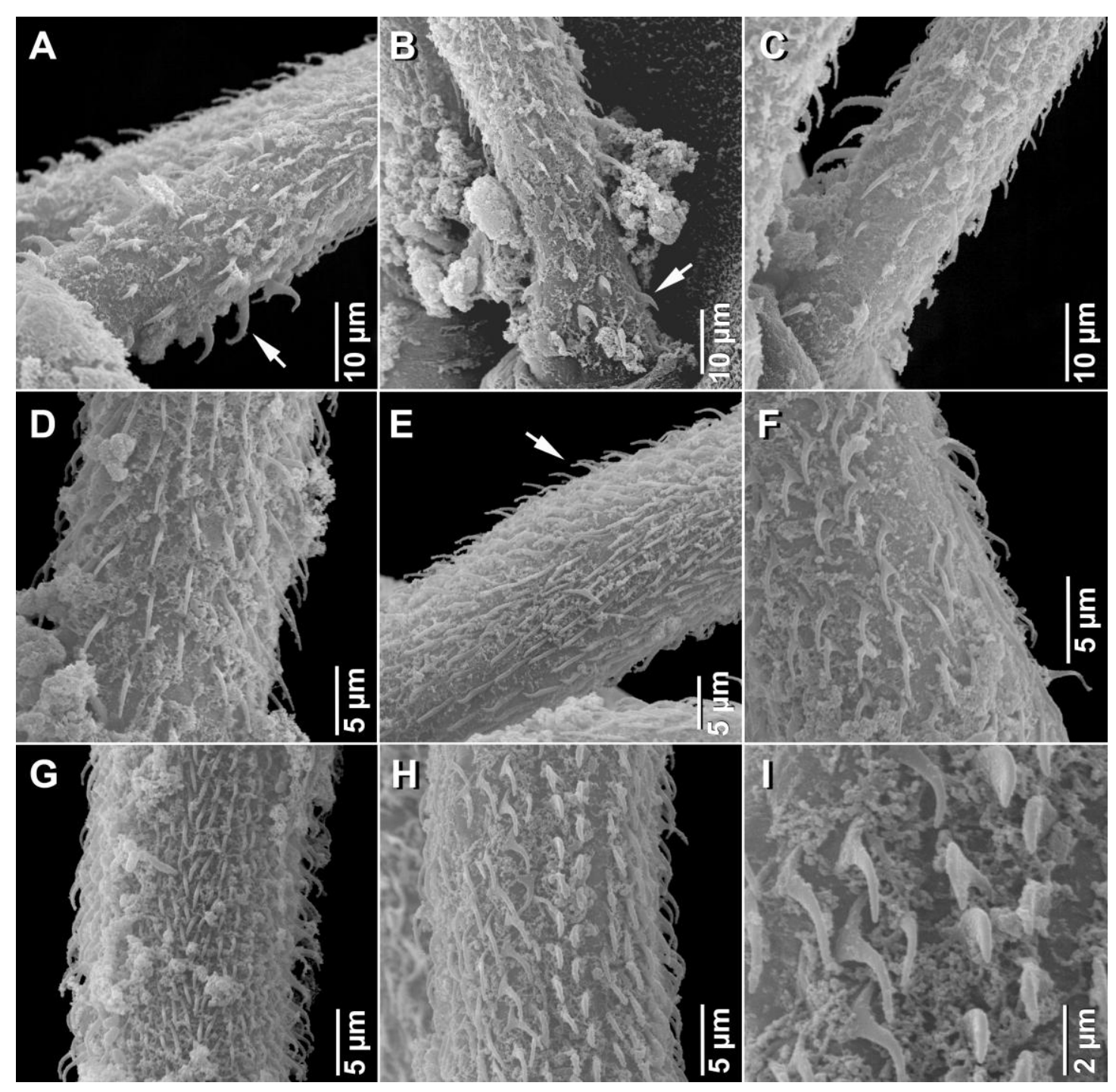




\section{University Library}

\section{- M M I N E R VA \\ A gateway to Melbourne's research publications}

Minerva Access is the Institutional Repository of The University of Melbourne

Author/s:

Schaeffner, BC;Beveridge, I

Title:

Poecilorhynchus perplexus n. g., n. sp (Trypanorhyncha: Eutetrarhynchidae) from the brownbanded bambooshark, Chiloscyllium punctatum Muller \& Henle, from Australia

Date:

2013-05-01

Citation:

Schaeffner, B. C. \& Beveridge, I. (2013). Poecilorhynchus perplexus n. g., n. sp (Trypanorhyncha: Eutetrarhynchidae) from the brownbanded bambooshark, Chiloscyllium punctatum Muller \& Henle, from Australia. SYSTEMATIC PARASITOLOGY, 85 (1), pp.1-9. https://doi.org/10.1007/s11230-013-9408-9.

Persistent Link:

http://hdl.handle.net/11343/282798 